\title{
Reshoring: a strategic renewal of luxury clothing supply chains
}

\author{
Pamela K. Robinson ${ }^{1}$ - Linda Hsieh ${ }^{2}$
}

Received: 4 January 2016 / Revised: 4 June 2016 / Accepted: 9 June 2016 / Published online: 30 June 2016

(C) The Author(s) 2016. This article is published with open access at Springerlink.com

\begin{abstract}
This paper contributes to the emerging literature on reshoring by taking a value-driven enquiry into the renewal of supply chain strategy. It enhances the understanding of the use of reshoring in generating the value demanded by a changing business model. An iconic British high-end clothing brand, Burberry, is the chosen case study to explore the recent move towards reshoring because its changes of leadership, business model and evolving supply chain strategy from 1997 to early 2016 provide a timely and pertinent context. Burberry has continued to realign its business towards a brand-led and customer-centric model along with restoring its corporate heritage and core brand values. The changes in Burberry's business model triggered the need to renew and realign its supply chain strategy through consolidating and rebuilding manufacturing activities back in the UK, in order to support its brand repositioning as quintessentially British and the company's refocus on heritage products. The increased managerial control in the supply chain together with the close proximity of design and manufacture enables the promise of quality and brand provenance to be fulfilled. The renewal of Burberry's supply chain strategy has contributed to an increase in revenues and brand values. These findings suggest that the renewal of supply chain strategy through reshoring and increasing control in supply chain operations can enhance value and firm competitiveness.
\end{abstract}

Pamela K. Robinson

p.k.robinson@bham.ac.uk

Linda Hsieh

hh24@soas.ac.uk

1 University of Birmingham, University House, Edgbaston, Birmingham B15 2TT, UK

2 SOAS, University of London, London WC1H 0XG, UK
Keywords Burberry $\cdot$ Reshoring · Supply chain strategy · Renewal

\section{Introduction}

During the last two decades, or so, lead firms in apparel value chains have adopted a strategy of offshore outsourcing of the manufacturing process to a global network of suppliers (Pickles et al. 2015). Despite the fact that this trend is likely to continue, the operational challenges and increasing cost in global supply chain management have prompted some firms to reconfigure their value chain activities, including facility relocation or changing supply bases back to their home country (Ancarani et al. 2015). Developments in automation and robotics have gradually eroded the comparative advantage enjoyed by low-cost manufacturing countries (Kinkel 2014). Reshoring also makes the supply chains of apparel firms more traceable (Key Note 2015), and according to a survey by EEF/ Squire Sanders, one in six companies reshored production back to the UK between 2011 and 2014. The return of production activities back to the home country of the parent firm regardless of ownership of the relocated activities is commonly referred to as reshoring (Ellram et al. 2013; Gray et al. 2013). It is a voluntary decision by companies as well as a possible step in a firm's internationalization process (Fratocchi et al. 2015). Some studies (e.g. Kinkel and Maloca 2009; Kinkel 2012) conceptualize reshoring as a mere corrective strategy of previous location misjudgements. Nevertheless, reshoring is as an important strategic decision made by firms to establish and capitalize on the use of 'country of origin' as a competitive base, especially in high-end/ luxury apparel market segments (Brun et al. 2008).

Some UK high-end apparel firms (e.g. Barbour, Burberry, and Mulberry) have reshored part of their key production 
processes to re-establish product authenticity/country of origin in response to a growing demand for British-made fashion. The brand appeal of 'Made in Britain' or Britishness is a highly valuable marker of authenticity, superior quality, and indicator of tradition in luxury fashion, which in turn, contributes to justifying premium pricing (Goodrum 2005; Key Note 2015). Moreover, associated with this reshoring trend has been a growing awareness of the importance of combining local and global sourcing and production activities to swiftly meet ever-changing consumers' requirements and to optimize the trade-off between cost savings and agility in apparel supply chains (Macchion et al. 2015; Purvis et al. 2014). The clothing market is a dynamic globalized sector. The renewal of firms' supply chain strategy through reshoring is therefore not all about lowering costs. Firms are beginning to look at their manufacturing location decisions and consider their implication on customer value creation, market position and competitive advantage (Bruce and Daly 2011; Caniato et al. 2011; Ellram et al. 2013). However, a valuedriven enquiry into the renewal of supply chain strategy through reshoring has received relatively little attention in empirical studies, as most previous research has focused on understanding the business drivers and the scale of reshoring (Bailey and De Propris 2014; Fratocchi et al. 2014). Too much emphasis has been placed on such issues as cost, risk, and control along supply chains.

Hence, our paper focuses on the renewal of supply chain strategy and the appropriateness of reshoring for luxury branded goods where efficacy and authenticity of the brand have become a consumer-driven requirement. This is particularly pertinent for firms wishing to ensure the provenance of their product proposition and maintain comparative advantage in a highly competitive market sector. More specifically, we attempt to answer the question of how the renewal of supply chain strategy through reshoring enhances value and firm competitiveness. Our primary contribution is to enhance the understanding of the use of reshoring in generating the value demanded by a changing business model. A business model defines the way a firm operates to expedite its strategy and how it creates and delivers value to customers (Casadesus-Masanell and Ricart 2010; Teece 2010). Additionally, our paper adds to relatively limited empirical evidence on the "made-in-effect" which is one of the value-driven motivations in reshoring (Fratocchi et al. 2016).

Burberry is an iconic British high-end clothing brand. Despite the market stumble and brand crisis in the 1990s, Burberry gradually recovered from its corporate heritage brand debacle throughout the 2000s (Cooper et al. 2015). Burberry, internationally recognised for its trademark check plaid, makes for an insightful case in our study on the revival of high-end fashion manufacturing in the UK. Not least because it is the most valuable British brand after HSBC according to the 2015 Interbrand index and its brand value has grown significantly since 2011 to reach a value of 5873 million US dollars in 2015 (Interbrand 2015). Burberry continues to realign its business towards a brand-led and customer-centric model along with restoring its corporate heritage and core brand values, all of which entails an injection of more Britishness into its core supply chain. Burberry, thus, provides an interesting context for studying the renewal of supply chain strategy through reshoring.

This paper is structured as follows: The next section provides a brief review of supply chain strategy and reshoring literature, followed by an explanation of the renewal of supply chain strategy through value-driven reshoring and the context of a clothing manufacturing revival in the UK. The third section briefly describes the case study methodology. We then present our analysis of the Burberry case study. The fifth section develops our discussion based on the case study and the final section concludes with some thoughts regarding the possible implications for managers and policy makers and avenues for future research on reshoring.

\section{Literature review}

\subsection{Supply chain strategy}

The concept of 'supply chain strategy' has been widely used by academics and practitioners. Most discussions of the concept relate it to the pattern of decisions concerning supply chain activities that include 'sourcing products, capacity planning, conversion of raw materials, demand management, communication across the supply chain, and delivery of products and services' (Narasimhan et al. 2008, p. 5234). The sourcing and distribution channel activities of firms are key components of its supply chain strategy, and based on demand and supply uncertainties, Lee (2002) distinguished four categories of supply chain strategy. One is the efficient where 'strategies aimed at creating the highest cost efficiencies in the supply chain' (p.113). The second category is riskhedging referring to 'strategies aimed at pooling and sharing resources in a supply chain so that the risks in supply disruption can also be shared' (p.113). The third category is the responsive 'aimed at being responsive and flexible to the changing and diverse needs of the customers' (p.114). The fourth category is the agile referring to strategies aimed at 'being responsive to the changing, diverse, and unpredictable demands of customers on the front end, while minimizing the back-end risks of supply disruptions' (p.114). His later published work (Lee 2004) argues that the best supply chain strategy is 'agile', 'adaptable', and 'aligned'. This indicates that as global competition intensifies, firms must think beyond the traditional view of supply chain, which emphasizes speed and operational efficiency and will need to embrace a value- 
creation mind-set when designing supply chain strategies (Kim 2013). Thus, a supply chain strategy needs to combine both value creation and operational supply chain points of view (Holweg and Helo 2014). More recent studies, e.g. Kim 2013; Roh et al. 2014; von Massow and Canbolat 2014, have begun to conceptualize supply chain strategy in that it defines the chief objectives for the supply chain in terms of adding value to the competitive strategy as well as contributing to meeting the strategic objectives of firms.

In general, the fashion apparel industry is divided into three market segments based on a firm's competitive strategy: speed, cost advantage, and brand equity (Mehrjoo and Pasek 2015). Luxury and high-end fashion falls into the market segment of brand equity. In this regard, there are a number of critical success factors to be considered; namely, style and design excellence, country of origin (the made-in effect), the coherence between brand value/reputation and product uniqueness that conveys appropriate emotional appeal needed to satisfy customers and superior product quality (Brun et al. 2008). These factors can affect the design of supply chain strategies. For example, Moore and Fernie (2004) found that Gucci's repositioning of itself as a luxury brand was accomplished by maximizing internal controls of product sourcing, distribution, and brand communications. In a similar vein, Brun and Castelli (2008) indicated that Fratelli Rossetti, a luxury Italian shoe brand, keeps a vertically integrated supply chain for its heritage products. It outsources the manufacturing of other products to other Italian firms in the same district in order to preserve the authenticity of 'Made-in-Italy' label. Kim (2013) found that Louis Vuitton and Chanel adopted a 'concentrated' supply chain strategy that consists of in-house sourcing and centralized distribution channels.

The foregoing review has highlighted a firm's supply chain strategy and practices are shaped by its competitive strategy and business model. In luxury apparel, brand image is critical to 'effective positioning' (Collins and Weiss 2015) and it should be carefully managed and supported by a valuedriven configuration of local and global sourcing and production. As a firm's business model evolves with changing global competitive conditions, supply chain strategy has to be renewed or adapted to assure competitive advantage. This may sometimes involve changing from outsourcing to inhouse sourcing and production and/or relocating these activities from foreign to home countries. The latter focuses on how to locate sourcing and production that has increasingly become a strategically important decision to multinational corporations (Buckley and Ghauri 2004). Moreover, as savvy consumers in luxury markets become more concerned with the provenance of products, firms need to be more wary about the potential negative consequences of relocating production out of their country-oforigin (Collins and Weiss 2015).

\subsection{Renewal through value-driven reshoring}

Reshoring of once offshored activities has attracted growing attention as a subject of academic enquiry and a goal of public policy. Gray et al. (2013, p.28) identified four reshoring options. The first option is in-house reshoring, which refers to 'relocating manufacturing activities being performed in wholly owned offshore facilities back' to wholly owned domesticbased facilities. The second is reshoring for outsourcing 'by relocating manufacturing activities being performed in wholly owned offshore facilities back' to domestic-based suppliers. The third is reshoring for insourcing 'by relocating manufacturing activities being performed by offshore suppliers back' to wholly owned domestic-based facilities. The fourth option is outsourced reshoring 'by relocating manufacturing activities being performed by offshore suppliers back' to home-based suppliers.

As previous studies (e.g. Gray et al. 2013) suggest, some firms might have followed a herd instinct to offshore sourcing and production activities, leading to a miscalculation of benefit, cost and risk of offshoring. Another possible negative consequence could be that offshoring does not support a company's brand and match its value proposition for consumers. Largely, firms considering the impact of offshoring and outsourcing production on total costs, profitability, and customer value creation drive the reshoring phenomenon (Ellram et al. 2013). From this total cost perspective, the shrinking labour cost differentiation between offshore countries and Western economies, high transportation and logistics costs, and the higher than expected costs associated with coordination and quality control over supply chain partners in foreign locations, have led some firms to return production to their home countries (Bailey and De Propris 2014; Fratocchi et al. 2014; Macchion et al. 2015). The psychic distance (e.g. differences in culture, language, business practices, legal and political systems) between home and host country may lead to managers underestimating the costs of implementing offshoring decisions, thus increasing the likelihood of reshoring (Ancarani et al. 2015). From a supply chain perspective, the potential for disruption in the chain, delivery delays, long responsive times to replace poor quality products and a loss of flexibility and agility have also contributed to the decisions made by firms to rethink their sourcing strategy and reshore production (Gray et al. 2013). Accordingly, reshoring has been viewed as a sheer consequence of learning and correcting the previous misjudged offshoring decisions (Kinkel and Maloca 2009; Kinkel 2012, 2014). Moreover, some firms reshore because they recognise the benefits of co-location of design/R\&D and manufacturing and its impact on innovation (Fratocchi et al. 2015; Pisano and Shih 2012). For example, Pisano and Shih (p. 96) argued 'design cannot be separated from manufacturing' in the high-end apparel industry because design/aesthetic innovation and product 
quality are affected by how a fabric is cut and sewn into shape. The value of co-locating design with manufacturing is therefore high.

To date, the research on reshoring has focused mainly on the deterioration of locational advantages in offshore countries, hidden cost and risks in supply chain management and the opportunities and impacts of reshoring on home country economies and the reaction of consumers towards corporate reshoring and the 'Made in' or 'country-of-origin' factor has been paid limited attention (Ellram et al. 2013; Fratocchi et al. 2016; Grappi et al. 2015). Consumers' perception of value in relation to these two factors can influence their intention to buy and pay, ultimately affecting company performance. In view of the above, reshoring thus can be understood as a renewal of supply chain strategy which helps to reshape and improve a firm's competitiveness in the global economy and to enhance its value creation for consumers. Reshoring becomes a sensible and plausible alternative to offshoring when firms perceive a need of adjustment in order to protect or reinvent the critical attributes (e.g. innovation, quality, and made-in-effect) that influence customers' preferences (Fratocchi et al. 2016). In addition, Caniato et al. (2013) proposed that a value chain perspective should be incorporated into understanding the supply chain of luxury fashion companies because these companies often pursue competitive advantage over rarity and brand exclusivity. In line with this, we argue that a value-driven enquiry into the renewal of supply chain strategy through reshoring is imperative to understanding reshoring in the high-end apparel sector.

\subsection{Context of a clothing manufacturing revival}

In the late-1990s UK clothing firms faced the growing pressures of rising costs, a downward spiral of retail prices and a turbulent economic climate. The garment and textiles industry in the UK depended on a low-capital and labour intensive operation and as production costs increased with little opportunity to pass these costs on, many branded fashion manufacturers were forced to reconsider their business model. Firms looked to source more of their wares overseas and to subcontract production to more economically viable locations, and so manufacturing in low-cost labour regimes became the norm for clothing firms based in developed economies (Christopher et al. 2004; Dicken 2007).

It was during the 1990s that the once dominant UK clothing sector suffered its greatest decline, a move underlined by the symbolic decision by Marks and Spencers, one of the country's stalwart procurers of British-made fashion, to licence production overseas (Allwood et al. 2006). From the mid-1990s onwards, UK clothing firms have adopted the strategy of outsourcing production to low-wage countries (Lane and Probert 2006). In 2011, the Oxford Economics estimated that the value of UK fashion manufacturing had fallen by two-thirds since 1995 (cited by British Fashion Council, BFC 2012). This was a dramatic fall and one that coincided with increased competition from low-cost producing countries, particularly China, Bangladesh and India (Allwood et al. 2006), and the emergence of fast- and easily castoff- fashion.

However, more recently some UK clothing firms are reviewing their supply chain strategy of 'arm's length' manufacturing and outsourced operations (Foresight 2013). A growing demand for fashion products with a 'Made in Britain' label has led to a renaissance in UK clothing manufacturing. Once seen as a label that consumers should be weary of, it is viewed now as a badge of quality (Khan 2015). During the last few years, a number of high-street retailers have launched 'Best in British' ranges, including Marks and Spencer' ${ }^{1}$ and John Lewis, ${ }^{2}$ whilst other well-known fashion brands have restarted production in the UK having left a decade earlier to go to Asia, such as the Arcadia group, which includes the major high-street brands Top Shop and Dorothy Perkins (Foresight 2013). One of the key advantages cited for this return is flexibility - the opportunity to adapt to changing consumer's preferences - something that could only be achieved by greater control of the supply chain and shorter lead times. The ability to react to what sells well, whilst halting production of lines doing less well, can help retailers maximise their sales in ever-quicker fashion-cycles and mitigate the risk of markdowns. By exploiting the strength of 'Made in Britain' supply chain, UK clothing firms can become more competitive in markets characterised by flexibility, short runs and rapid delivery (McLaren et al. 2002).

According to industry experts and Oxford Economics, clothing's share of UK manufacturing output has grown since 2009 and its share of manufacturing employment output has grown from $2.0 \%$ to $2.5 \%$ between 2009 and 2010 (cited in British Fashion Council, BFC 2012). This suggests that the return of UK clothing manufacture is gaining momentum, both for mass-market garments and high-end fashion. The appeal of domestic production is manifold - higher overseas labour costs, increased transportation charges, difficulties in sourcing raw materials, the prioritisation of domestic production in China, a revival of traditional 'British' fashion, and a growing concern for environmental and ethical standards in far-flung production sites (Felsted 2014; Key Note 2015). These factors have led to a revision of possible supply chain configurations for fashion, and as such, signal a shift back to UK-based production. Since 2007, clothing manufacturing

\footnotetext{
${ }^{1}$ Made from materials that are sourced, woven, dyed, printed and made in the UK, the M\&S 'Best of British' range demonstrates the trend to source within Britain, and emphasises the provenance of the product whilst at the same time enabling the retailer to manage the soaring cost rises in China (Felsted 2014).

${ }^{2}$ In 2013, John Lewis announced its plans to increase sales of its 'Made in the UK' products by a minimum of $15 \%$ by 2015 to $£ 550 \mathrm{~m}$, as part of its commitment to using more domestic suppliers (Foresight 2013).
} 
has seen a striking revival due to the adaptation of existing business models: the return of production to the textile heartlands of the East-Midlands, Yorkshire and Lancashire and the new business model of on-line retailing (Key Note 2014). Clothing manufacture has increased significantly in the UK, between 2008 and 2012 the industry grew by almost $11 \%$, a phenomenon that Hammer et al. (2015) suggest is largely based on the advantages of the fast-fashion business model, i.e. small batch production with short lead-times which can be reordered with stock requirements adjusted and hence, eliminating the need to hold large stocks. Nevertheless, in high-end fashion there are other distinct characteristics driving the revival of manufacture in the UK. For British-inspired brands keen to take advantage of their unique features of heritage, tradition and superior quality, the need for close proximity between designer and producer is paramount - a requirement that impacts the decision-making process of make or buy further upstream in the supply chain.

The research questions that underpin this paper focus therefore, on the renewal of supply chain strategy and the appropriateness of reshoring luxury branded goods where efficacy and authenticity of a brand is both a marketing ploy and a consumer-driven requirement. This is particularly pertinent for firms wishing to protect brand equity and pursue comparative advantage in a highly competitive market sector.

\section{Methodology}

The paper is based on a series of 23 semi-structured interviews, conducted between July 2014 and December 2015, which involved senior managers in 3 suppliers manufacturing for the UK high-end branded clothing market and 2 suppliers manufacturing for UK high-street retail brands, 6 industry experts, 4 fashion designers who had previously worked at Burberry, and further discussions with 8 representatives from Burberry across different functional areas including design, product development, marketing, and supply chain. In order to develop a coherent and comprehensive approach to the enquiry secondary data sources were also sought, these consisted of corporate documents, fashion industry association reviews, market intelligence surveys and consultancy reports. There were three distinct phases of the research study that underpin the paper, including: (i) Documentary and database searches, (ii) Initial discussions with representatives of luxury fashion brands and potential gatekeepers, and (iii) Semi-structured interviews. The research approach adopted was qualitative in nature and aimed to explore the sourcing strategies of firms operating internationally in the luxury fashion sector but whose origins were quintessentially British. Hence, the strategy to recruit research participants involved two sampling frames; the first was based on previous research and a register of UK-based manufacturers for the high-end fashion market, and the second, was based on a professional network established through prior employment in the retail industry. We adopted the sampling technique described by Lincoln and Guba (1985) as 'purposeful' in selecting informants, which also led to referrals of additional respondents due to a snowballing effect. Our intention was to speak to individuals who had a role within the design, marketing and supply chain functions of high-end branded fashion houses, either in terms of decision-making or actual manufacturing responsibilities. Since this is a convenience sampling technique, we have avoided making any generalisations from our findings.

Our investigation follows the tradition of a case study analysis. Yin (2009, p.18) describes this approach as 'an empirical inquiry that investigates a contemporary phenomenon in depth and within its real-life context, especially when the boundaries between phenomenon and context are not clearly evident'. The case study approach is driven by a compelling need to build a comprehensive understanding of a single or small number of cases set in a real-life setting (Bromley 2002). The term case study identifies a specific form of research enquiry, with 'a range of dimensions', one of the more important dimensions being 'the number of cases investigated' followed by 'the amount of detailed information that the researcher collects about each case studied' (Hammersley and Gomm 2004, p. 2). The case study affords the opportunity to gather and analyse information about a large number of features of each case, the emphasis being on the qualitative nature of the data rather than the quantification of data, and as such, the case study approach leads to a more narrative approach (Hammersley and Gomm 2004). A narrative gives a largely descriptive and sequential account of a particular social phenomenon or case, and hence, the approach requires real-world data to be mapped onto a theoretical framework in order to express it as a substantive argument (Bromley 2002).

Qualitative research implies an emphasis on the qualities of entities and on processes and meanings that are not experimentally examined or measured (if measured at all) in terms of quantity, amount, intensity, or frequency (Denzin and Lincoln 2000, p.8). In this regard, we do not attempt to generalise from this case study, but merely indicate there is a nuanced change in the sourcing model of high-end clothing brands that is worthy of greater observation (Gerring 2004). A case study research design enables the exploration of the business environment and conditions of a specific sector whereby theoretical ideas may be developed (Hammersley and Gomm 2004).

Theoretically, the supply chain model of 'make or buy' helped to frame the analysis phase of the study. Based on the interview data and secondary sources of information an outline of key business model events and decisions in the history of Burberry was constructed. This provided the framework to conduct a thematic analysis of the data and develop an understanding of the shifts in Burberry's sourcing strategy and 
subsequent consequences for the business at each stage a new CEO was appointed in the organization. Anonymity and confidentiality arrangements for the interview process and subsequent discussions were agreed with the participants involved, and in order to ensure this, respondents' testimonies were organized in a way that enabled the authors to identify the commentary and develop further understanding of the issues faced in the sector relative to the respondent's role in the highend clothing value chain. The additional data collected was organized in a similar manner and this helped to build on the number of overarching themes already constructed and facilitated further analysis through the use of the qualitative software NVivo. In this respect, the organization and assembling process represents the decisive link between the original raw data: documentary sources, interview transcripts and the theoretical concepts employed in the research and as such, provides an opportunity to interpret and reflect on the information gleamed (Miles and Huberman 1994).

The methodological framework that guides the process of data collection and analysis is based on the value chain developed by Porter (1985). To address the initial research question the types of business model that currently exist in the high-end clothing sector and those that are evolving together with the driven-ness (control) of the supply chain are of key interest. In this respect, the methodological approach adopted was to follow the chain from supplier to retailer and back again, particularly when respondents identified additional points of contact. The research design has been developed in a way that helps to draw upon a sectoral and business network that offers access to participants within a given value chain. The approach of relying on corporate contacts as informants, however, poses certain challenges in terms of bias in sampling and the requested and often necessary commitment for anonymity and confidentiality of the interviewee. Based on the process of gaining access to an elite research setting, sampling bias may be unavoidable (Welch et al. 2002), but this can be mitigated by drawing on other datasets, e.g. documentary and other sources of information in the public domain (Miles and Huberman 1994). The findings discussed herein are based on an inductive, interpretive case study of a high-end fashion brand that rediscovered its core values and transformed their supply chain in order to deliver the quality and experience for which the company was once renown.

\section{Case analysis of Burberry}

\subsection{Foundation and corporate heritage brand crisis}

Burberry is a UK-based, but internationally recognised, company engaged in the design, sourcing, manufacture and distribution of luxury apparel and accessories via owned retail stores, concessions, and wholesale and licensing agreements (Key Note 2014). Founded in 1856 by the mill-owner and London-based dressmaker Thomas Burberry, the company's market breakthrough came in 1888, when Thomas developed a material called gabardine. Gabardine was a highly waterresistant, breathable and extremely hardwearing material and it became the very fabric of the firm's success when used to create the iconic Burberry trench coat (Burberry 2010). The new fabric best suited military needs and with the addition of some functional elements such as epaulettes and straps, it became standard issue for British officers during the First World War (Moore and Birtwistle 2004). The military connection and the creation of a distinctive check lining in the 1920s led to the launch of the Burberry trench coat and in less than a century later the company became a worldwide luxury brand (Burberry 2010). Burberry soon established itself as a British Institution in the luxury goods market, helped in no little part, by the actors Humphrey Bogart and Ingrid Bergman who were both seen wearing its iconic trench coat in the 1942 film Casablanca (Tokatli 2012).

However, the company and the brand experienced turbulent times during the late-1980s and early-1990s. The initiation of product-licensing agreements with third-party manufacturers in Spain and Japan during the 1960s and 1970s had untold consequences for the brand. The initial challenge of managing such arrangements led to a much more damaging problem for Burberry as licensees provided discounted products sourced from Asia to the European market to be sold alongside the higher priced British-manufactured items (Tokatli 2012). The flood of manufactured goods from Asia also enabled the supply of counterfeit products, which added to the loss of control for Burberry in terms of who its customer was and how the brand was being viewed in the luxury market (Collins 2009; Tokatli 2012). The opportunity for cheaper Burberry items enticed new customers, but as sales increased the exclusivity and aspirational position of the brand was undermined. The adoption of the Burberry check pattern by football fans in the UK during the 1980s further threatened the firm's market position and contributed to the loss of the brand's 'cachet' (Collins 2009). A lack of control of licensees in the supply chain and a somewhat flawed marketing strategy challenged the quality-perception of Burberry and the uniqueness of this quintessential British brand. By 1997, the brand was seen as appealing only to middle-aged men and was considered to be lacking innovation and creativity (Collins 2009; Cowe 1998). Subsequently, company profits suffered a drop from $£ 62 \mathrm{~m}$ to $£ 25 \mathrm{~m}$ and Great Universal Stores who had acquired the brand in 1955 were advised to sell-off Burberry (Finch and May 1998).

The tired and somewhat outdated brand was badly in need of a makeover and drastic action was required. Figure 1 shows a chronological organization of critical turning points after the corporate heritage brand crisis. It highlights the changes of 
leadership, business model and supply chain strategy in the history of Burberry from 1997 to early 2016.

\subsection{The era of Rose Marie Bravo}

In 1997, a new CEO, Rose Marie Bravo, was hired to revitalise the glamour and status that Burberry had experienced in its heyday. When Bravo took the helm she understood the value of the brand and that it's 'Britishness' was its most effective marketing tool (Blank 2015). However, the initial priority was to reinvent the firm into a modern luxury brand and Bravo was relatively successful in achieving this by regaining control of Burberry's unwieldy licensing and distribution structure (The Economist 2001). In spring 2002, the publication of an IPO prospectus for Burberry highlighted the challenges faced in 1997 and a strategy for renewal of the brand was announced (Burberry IPO Prospectus 2002). The Burberry trademark was acknowledged as a critical asset of the company and all attention was focussed on how to reposition Burberry as a contemporary and credible high-end fashion brand (Moore and Birtwistle 2004). Moreover, when Rose Marie Bravo took on Burberry, it had a relatively small international profile. The dramatic turnaround needed for the company began in 2001, with the appointment of a British designer, Christopher Bailey. Bailey, who had a track record with a number of international luxury fashion groups including Gucci and Donna Karan, was passionate about rejuvenating the Burberry brand and reinstating its Britishness (Moore and Birtwistle 2004; Pike 2013). By 2003-04, Burberry had achieved solid growth across Europe, the US and Asia Pacific and had opened new stores in Australia, Hong Kong, Singapore and Kuala Lumpur.

\subsection{The era of Angela Ahrendts}

The incoming CEO Angela Ahrendts, following other luxury fashion houses, overhauled the Burberry brand in 2006 - her focus became the 'value' of Burberry's heritage and the firm's 'Made in Britain' credentials. The repatriation of production back to the UK in order to ensure the brand's authenticity of design was critical to this move (Ahrendts 2013). As suggested by a retail consultant acting in an advisory capacity to the company at the time:

"It's all about the Britishness of the product... consumers in China don't want to buy a Burberry trench coat made in Shanghai... they want the real thing, it has to be truly made in England... it's the craftsmanship and heritage of the brand that consumers in emerging markets are buying into" (Interview, September 2015).

Because the Chinese market represented over $30 \%$ of the company's sales at the time, the migration of manufacturing back to the UK was clearly an important change to the existing supply chain configuration (Interview Retail Consultant, September 2015).

The year 2006 also marked the beginning of a new era of celebrity endorsement for Burberry. According to an interview with a junior designer, Burberry encouraged a number of wellknown British celebrities such as actors, sports personalities and other recognisable British trendsetters to showcase their clothing, luggage and handbags by providing free samples "which was a first for Burberry" (September 2015). Although this proved a little problematic when a number of internationally acclaimed Welsh singers and actors, including Tom Jones, Rhys Ifans and Ioan Gruffudd, burnt their trench coats in protest at the closure announcement of the Burberry plant in Treorchy, South Wales in 2007 (Jones 2007).

Ahrendts had inherited a fragmented business consisting of 23 international licensing agreements and a brand so stretched that it was used to merchandise dog leashes and kilts in its London flagship store (Ahrendts 2013). In order to manage costs and refocus the business, Ahrendts initiated a major restructuring of the firm's supplier base, and a number of plant closures followed, including the closure of one of the firm's two Yorkshire factories producing their classic trench coat in 2009. The global recession and the need to weather the difficult trading environment were cited as the reasons for backtracking on earlier commitments to manufacturing plans for the UK (Tokatli 2012). This change of heart resulted in a large proportion of Burberry products becoming reliant on overseas sourcing from full-packaged manufacturers ${ }^{3}$ - which entailed the ceding of control for a number of operational activities including procurement and design-related responsibilities to third-party producers (Tokatli 2012).

Burberry had a history of mixed UK and offshore sourcing, but the need to maintain competitive advantage and strengthen the company's luxury position in the global market were the reasons cited for overseas manufacturing becoming standard practice once again (Jones 2007; Tokatli 2012). Nevertheless, Burberry's market position suffered from the criticism relating to moving some of its production abroad and closing UK factories. The high-profile media campaign in 2007 to stop the relocation of production to Asia - a move seen as an exercise to lower production costs - created a great deal of embarrassment for the brand (Blyton and Jenkins 2012). Loyal fans of the Burberry trench coat, including a number of well-known celebrities and actors supported the campaign to 'Keep Burberry British' (BBC 2007). Yet, Ahrendts still pressed on with the firm's cost efficiency programme and claimed that Burberry's classic trench coat would continue

\footnotetext{
${ }^{3}$ A switch to full-package manufacturing involves abandoning the cut, make, trim model and passing the risks and responsibilities of sourcing to manufacturing suppliers, which leads to the loss of a substantial degree of operational control (Tokatli 2012).
} 


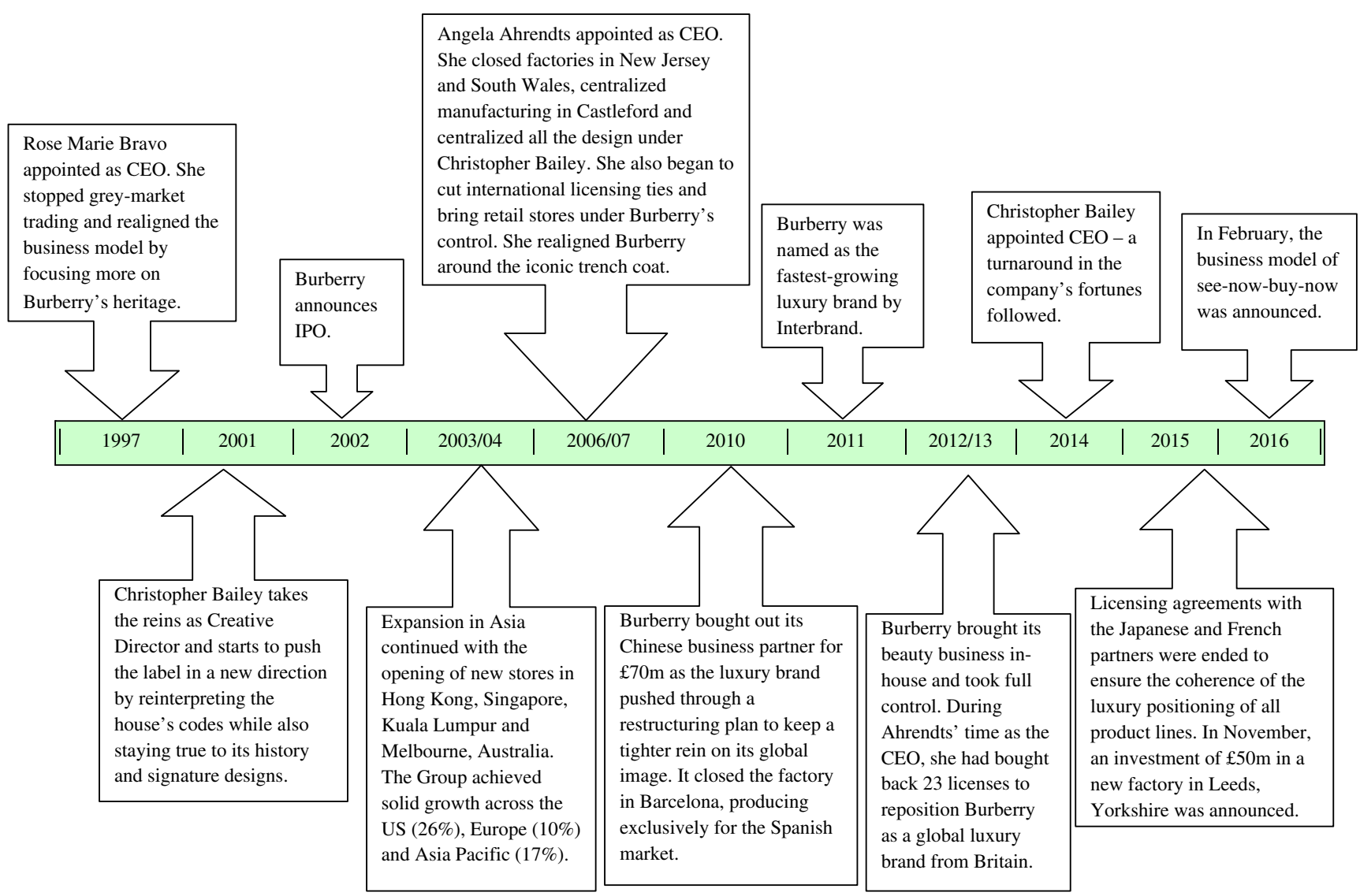

Fig. 1 Critical turning points after the corporate heritage brand crisis

to be produced at the company's own factory in Castleford, Yorkshire (Tokatli 2012).

However, following the public relations disaster of closing down Burberry factories in the UK, Bailey, who was still the firm's Chief Designer at the time, demonstrated his commitment to re-establishing the brand's core values. He saw the value of the brand in terms of 'dishevelled elegance' and was interested in presenting fashion items alongside things that had a real sense of heritage (Collins 2009). Bailey decided to hide the trade-mark Burberry pattern - so favoured as the lining of the classic trench coat - for a couple of seasons and then slowly brushed it down and added the famous check to a number of new products (Tokatli 2012). Ahrendts is credited with establishing the UK's only fashion brand to compete with the European houses of Vuitton, Prada and Gucci - largely achieved by refocusing the business once again on its iconic trench coat - but it was only when Bailey took over as CEO that the vision of the British super fashion brand was fully realised.

\subsection{The era of Christopher Bailey}

It was not until 2014, when Bailey finally took up the realm as $\mathrm{CEO}$, that he was able to revitalise plans to capitalise on the brand's heritage, "British roots are incredibly important to this brand" (quoted in Armstrong 2015) and the firm again built on its British heritage - the London Los Angeles show in 2015 even had the Queen's First Battalion Grenadier Guards take part. Bailey had come to realise that their core customers "... like that the cashmere is made in Scotland and the trenches are made in Yorkshire" (quoted in Armstrong 2015). These insights have helped to shape the strategic focus of the firm and the development of the brand. As such, Burberry has situated its iconic British-made trench coats and cashmere scarves at the core of its business, which Bailey stated was the 'heart' of Burberry's product offer (Burberry 2015a). Subsequently, every product event and initiative features the craftsmanship and heritage of the brand, whilst restating the British roots of the business (Burberry 2015a).

Moreover, the development of ICT has revolutionized the global clothing supply chain. Both Ahrendts and Bailey placed great emphasis on digital technology and they considered embracing new technology as Burberry's differentiator from other luxury competitors. Under the leadership of Bailey, Burberry has recently pioneered a new business model of 'See Now-Buy Now', which attempts to close the traditional sixmonth window between the catwalk and when clothing becomes available for purchase in stores. Such a structural change has a significant impact on Burberry's supply chain strategy. 


\subsection{Renewal of supply chain strategy: the impact on Burberry's values and competitiveness}

Supply chains in the apparel industry tend to be long, complex and involve a number of different parties. Since the increase of globalization and growth of international markets it is also usual to have intermediaries, e.g. an import or export agency that can source garment components from lower labour-cost manufacturing countries (Jones 2002; Popp 2000). However, all of these factors impact the quality and delivery of the product to market and require careful management of the supply chain.

As a British brand, Burberry continues to run operations from the UK, with design and product development controlled from its global headquarters in London. The company has two wholly owned UK manufacturing sites and heavily promotes its traditional heritage and domestic manufacturing. Burberry has been making its trench coat, a style classic, in Yorkshire since its first inception - the fabric is woven, cut, hand-sewed and finished in the UK at a rate of 5000 a week (Butler 2015). In some respects, the company bucked the trend for outsourcing its manufacturing to far-off climes, with Italy being the main country it turned to for sourcing materials and components from outside the UK. The mistake of closing manufacturing plants in the UK during the mid-2000s and the shift of production to Asia was "readily acknowledged but quickly glossed over" (Interview Supplier, October 2014).

The closure of factories in Europe and the US was to concentrate on production in Castleford, Yorkshire and to help Burberry re-emphasize its heritage product being made in Britain (Ahrendts 2013; Fernie and Grant 2015). More recently, commitments of investment in domestic production have been made $-£ 50 \mathrm{~m}$ plus to build a new factory in Yorkshire to ensure the manufacture of the trademark trench coat is firmly positioned back in the UK (Butler 2015). When making the announcement in November 2015 Bailey stated, "I' $m$ a massive believer in British manufacturing and the crafts and skills we have here. It is a tradition we should all be enormously proud of and continue to build on" and he continued, “... artisan skills and workmanship were important to Burberry as the label tried to compete on a world stage" (quoted in Butler 2015). Maintaining the production of Burberry's trademark trench coat in the UK, therefore, appears to be an ongoing corporate mantra, as indicated by a corporate affairs representative "Burberry has always produced its iconic trench coats in Yorkshire... and will continue to do so" (Discussion, March 2016). In June 2015, Burberry also terminated its licensing agreement (Burberry Blue and Burberry Black) with a long-standing Japanese partner, Sanyo Shokai, in an effort to take direct control of its business in Japan. This in turn allowed Burberry to reshore and use its global collections (a high-end line of trench coats and scarves) to build a consistent brand image globally (Chu and Fujikawa 2015).
For the same reason, Burberry terminated the contract licensing agreement with its French partner in the same year to bring the production of kids wear back in house.

With global sales of $£ 2.5 \mathrm{bn}$ in the financial year 2014-5 (See Fig. 2), Burberry is currently Britain's biggest luxury goods retailer (Burberry 2015a). Much of this achievement is due to the repositioning of the Burberry brand in the mind of the global consumer (Burberry 2015b). This is both a commercial and marketing feat, which in part may be attributed to the promotion of the quintessential Britishness of the Burberry brand and in part, because the return of manufacturing to the UK underpins the values of heritage and integrity associated with the Burberry label. By rebuilding manufacturing activities back in its home country and close to the product design team, Burberry has enabled a regeneration of the very brand values their core consumer's demand.

Moreover, the recent implementation of 'See Now-Buy Now' business model would need a more agile and seamless supply chain. It also requires concurrent designing and manufacturing rather than sequential development activities. Therefore, increasing domestic sourcing and manufacturing may shorten the supply chain and cut lead-times. However, the return to local manufacturing and the reenergising of the Burberry product portfolio is not without its challenges. The sustainability of the renewed Burberry business model is dependent on a number of factors, including the ability to control production costs and maintain high profit margins in an evercompetitive and fickle luxury market. In the past, cost and market pressures led Burberry to adopt a single product manufacturing strategy for some of its factory units in order to maximise production economies of scale (Blyton and Jenkins 2012). However, this change only weakened the position of individual factories and ultimately led to their closure, e.g. the Treorchy plant in South Wales producing polo shirts that was deemed to be 'not commercially viable' (BBC 2007). As a consequence, Burberry resorted to sourcing products overseas yet again and according to Angela Ahrendts (then CEO) delivered record profits for Burberry in 2009 (Burberry 2010). However, a refocus on the Burberry label

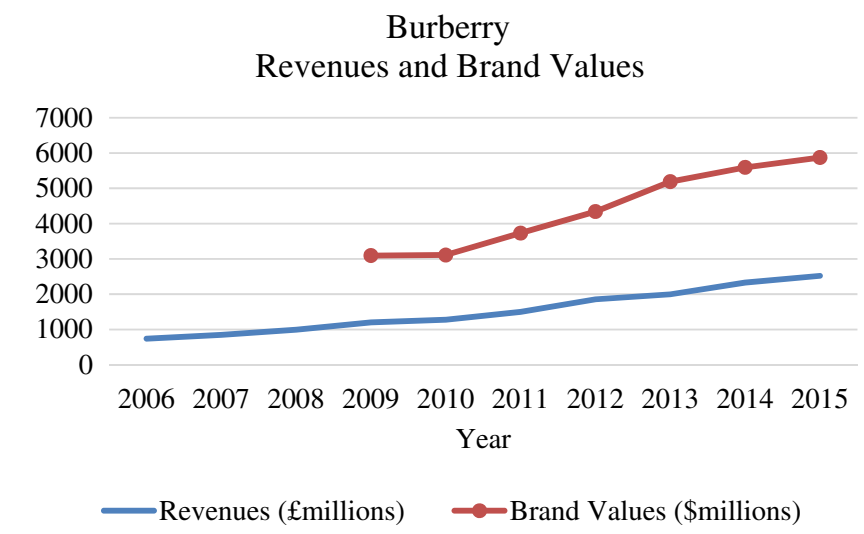

Fig. 2 Revenues and brand values of Burberry 
and its origins may prove significant in terms of the production location of the firm's iconic trench coat. For all its new status as a British luxury item, such a product still has to be made and delivered to stores in a timely and cost-efficient manner. The balance of managing demand, cost and market positioning of heritage brands in the future is therefore a tricky one.

\section{Discussion}

By the mid-2000s, luxury clothing was one of the fastestgrowing sectors globally (Bain and Company 2014), however Burberry was struggling to capitalize on their rich history and their classic trench coat - a product that was recognizable around the world. By 2006, Burberry's aggressive and flawed licensing approach had led to the loss of control over licensing and distribution of the brand. The Burberry brand had lost its exclusivity and was no longer compelling to the luxury consumer market (Pike 2013). The brands' unique strengths of heritage, quality and craftsmanship were under threat. However, this problem was not uncommon to other luxury brands that had adopted a business model of outsourcing and license manufacturing in the 1990s (Moore and Birtwistle 2004). During the same period, another British iconic brand Mulberry experienced problems of outsourcing to South China and the deterioration in the finish of its leather goods led to the return of manufacturing for their most exclusive range of handbags to their Somerset factory (based on interviews with Suppliers, October-December 2014). As our case finding illustrates, Burberry has been through a major shift in its business model during the last few years. This has led to the current model based on a single Burberry brand driven by a blend of its heritage, greater control over manufacturing and distribution by terminating or buying out licensing agreements, product focus rather than breath, and embracing digital innovation in fashion. The changes in Burberry's business model triggered the need to renew and realign its supply chain strategy through consolidating, rebuilding manufacturing activities back in the UK, its brand repositioning as quintessentially British and its refocus on heritage products.

Burberry's reshoring for insourcing (Gray et al. 2013), i.e. relocating manufacturing activities performed by offshore suppliers (e.g. trench coat licensee in Germany) back to wholly owned domestic-based facilities in the Castleford factory, can be viewed as a corrective to the previous strategy of overlicensing and offshoring as well as a response to the Burberry's changing business model. This finding also provides further support for Martinez-Mora and Merino (2014) which argued that companies offering premium or high-end products are more likely to reshore because their previous offshoring decision did not fit well with their changing business model that requires a shortened supply chain as well as a close control over the production process. Moreover, the renewal of Burberry's supply chain strategy lends support to the claim made by Fratocchi et al. (2015) that reshoring is a step in a non-linear internationalization process that is characterised by epochs of increasing or decreasing international activities of firms. According to them, firms might amend their previously implemented offshore production strategy by deciding to relocate production back to their home country, for example, Burberry's closure of the factory in New Jersey to consolidate production of its trench coat in the UK. Moreover, Burberry's previous widespread international licensing agreements led to the disconnect and loss of brand focus in its internationalization process. In an attempt to enhance its global positioning and to bridge the gap in brand perception between its global brand and license brand, Burberry returned to focus on its heritage products, centralized production in the UK, and took direct control of its previously licensed business in Japan. Therefore, reshoring and renewal of supply chain strategy are crucial to cement Burberry's position as a global luxury brand in its internationalization process.

Firms that offer branded goods in the luxury sector depend upon the superior quality of their goods and the ability to quickly respond to changing market trends (Aaker 1991; Macchion et al. 2015). This study confirms and extends Kim's (2013) findings, which maintain that a firm's supply chain strategy be aligned with its competitive priorities. Burberry's renewal of supply chain strategy through reshoring is seen as critical to re-establishing brand authenticity and the firm's repositioning as a British-made luxury brand. Bringing production back in house presents both opportunities and challenges to Burberry. It gives Burberry more control over manufacturing, marketing and distribution, lowers logistics costs, and reduces the firm's carbon footprint due to a shorten supply chain. However, the main challenge lies in balancing cost and market positioning of Burberry's heritage brand amid a challenging trading environment for luxury goods.

There are other British-born luxury brands in global markets that emphasise 'heritage' and 'authenticity' (e.g. 'Made in England' labelling), which has become a key consideration in the adaptation of the firm's business model in order to oversee production more closely. This is clearly demonstrated by the luxury brand Mulberry, whose range of handbags are designed in the UK, made from local supplies of leather treated in an English tannery, and although cut and assembled in Southern China, are finished and finally tooled in Yeovil, England (Interview Product Designer, October 2014). Although the labour cost savings of outsourcing the stitching process for handbags and a range of luggage items was soon to diminish and more recently Mulberry has been moving jobs from China back to Somerset. The need to more closely manage the quality - the look and feel of a product - was cited as the main reasoning for the turnaround (Interview Product Designer, October 2014). 
Hence, the competitive advantage of manufacturing in China and other far-flung destinations is gradually being eroded and there has been a surge back towards a UK manufacturing base for fast-fashion and some luxury brands (Foresight 2013; PwC 2013). As such, these firms are adapting and responding to the ever-changing consumer preferences for fashion, which require greater product variety based on the desire for more customised products, e.g. more fashionable/iconic pieces - that necessitate smaller production runs - and greater degrees of pricesensitivity in the marketplace (Key Note 2014). As a response to these demands some high-end clothing and fashion brand retailers have reviewed how best to maintain and protect the value proposition of their merchandise in what has emerged as a highly competitive retail market (Key Note 2014).

\section{Conclusion}

This paper aims to investigate how the renewal of supply chain strategy through reshoring enhances value and firm competitiveness. The Burberry case illustrates that the renewal of their supply chain strategy by increasing control in their supply chain operation is integral to the repositioning of their brand. This is most obviously seen in the re-launch of their cashmere woollen scarves made in Scotland and the recent campaign for the 'Made in England' range of outer clothing and their iconic trench coat. The key for both marketing activities is the notion of brand heritage and authenticity, and in this respect the increased managerial control in the supply chain together with the close proximity of design and manufacture enables the promise of quality and brand provenance to be fulfilled. Consequently, the renewal of Burberry's supply chain strategy contributes to the uplift in revenues and enhanced brand values of its merchandise.

\subsection{Managerial implications}

The increasing use of international supply chains and complex global subcontracting arrangements in the drive to create competitive advantage was proving problematic. There were a number of emergent factors that started to impact high-end clothing and luxury brand supply chains, factors such as shortened product lifecycles, raw material procurement costs, pressure on margins and the lack of control in the outsourced manufacturing process. The need for firms to quickly track their merchandise in order to ensure control of quality and inventory accuracy - the lean and agile supply chain - was becoming increasingly more important too (Christopher et al. 2004). Other benefits of bringing production closer to home included: streamlining safety, compliance auditing (labour codes of conduct and certification labels), reduced costs, increased workforce productivity, managing product recalls, minimised counterfeiting risk and other threats to brand authenticity. More recently, UK luxury firms have become concerned with protecting their brand equity and ensuring supply chain management adds value in the manufacturing process (PwC 2013). In order to promote brand value, Burberry along with other fashion houses, e.g. Mulberry, Paul Smith and John Smedley, have restated their product proposition to capitalize on the superior quality and craftsmanship synonymous with British goods and 'Made in England' labelling. The need to future-proof their competitive market position has influenced luxury brands to rethink the relationship between the design and manufacture stages of their operation - which in turn has led to the reconfiguration of entire product supply chains and the reshoring of manufacturing operations to the UK.

\subsection{Implications for policy makers}

Reshoring is a growing trend that has been identified as crucial to helping rebalance the UK's economy (De Backer et al. 2016). A number of issues appear to have influenced clothing firms to instigate the reshoring of key manufacturing activities to the UK, particularly in the case of luxury brands. Both clothing sectors, fast-fashion and the high-end luxury market, were impacted by the rising production costs in Asia, diminishing quality and the inflexible supply chains that prevent firms responding to changing consumer trends (PwC 2013; Bain and Company 2014). However, the problem for luxury branded firms was somewhat exacerbated as their business model depended on superior quality and timeliness to market - the hallmark values of their brand and product proposition. The manufacturers that emphasize the Britishness of their brands and as such, re-localised production to the UK - the rationale being their reputation for quality and heritage - have helped to once again reaffirm the UK manufacturing industry as a viable option (Foresight 2013). This is in spite of higher wage costs in comparison to international locations and other factors including the lack of adequate machinery. Even so, challenges exist for firms reshoring and relocalising their manufacturing base, e.g. the small skill base, which makes domestic production more expensive. Such conditions indicate that the renewal of clothing manufacturing in the UK is best suited for the luxury, high-end, designer clothing market, where production costs can be passed along the supply chain and reflected in the final retail price (Key Note 2014). Mass-market fast-fashion will continue to seek out low labourcost manufacturing wherever in the world it exists.

Nevertheless, there has been some additional marketing support for firms returning manufacturing operations to the UK. In particular, the UK government has capitalised on the global success of the London Olympics in 2012, and supported the development and branding campaign of 'Business is GREAT'. National pride and the demand from luxury export markets have together resulted in a 'Made in the UK' label becoming more welcoming to consumers. As such, the highend luxury sector is currently championing the trend for quintessential Britishness, in terms of both design and 
manufacturing. One brand that has most definitely maximised its British heritage in the marketplace is Burberry - a commitment to more localised manufacturing that has clearly proved popular with their globalized consumer base. In addition to the initiative of Reshore UK in 2014, policy makers need to embrace and foster industry-based training in order to address the issue of skills shortage in the longer term. In the short to medium term, if greater restrictions are to be placed on immigration policies, the labour sourcing strategy of UK clothing firms may become problematic. This in turn could lead to an unsustainable ecosystem for reshoring.

\subsection{Limitations and suggestions for future research}

The study presented here has a number of limitations that further research could aim to overcome. One of the limitations is that the case finding of Burberry might not be generalisable to other luxury clothing firms. Future studies with a larger sample that include luxury-clothing cases from other countries are encouraged. Second, the reshoring attempt by Burberry has only happened recently. It is therefore difficult to assess the impact of the renewed supply chain strategy on company performance. Thus, a longitudinal research design would naturally provide a more detailed picture and a better understanding of its relationship to performance and value creation. In general, there is a need to understand whether the reshoring process adopted by firms from Western economies is sustainable or not and what future capability these firms need to implement a sustainable reshoring strategy.

Open Access This article is distributed under the terms of the Creative Commons Attribution 4.0 International License (http:// creativecommons.org/licenses/by/4.0/), which permits unrestricted use, distribution, and reproduction in any medium, provided you give appropriate credit to the original author(s) and the source, provide a link to the Creative Commons license, and indicate if changes were made.

\section{References}

Aaker DA (1991) Managing brand equity: capitalizing on the value of a brand name. The Free Press, New York

Ahrendts A (2013) Burberry's CEO on Turning an Aging British Icon into a Global Luxury Brand. Harvard Business Review, JanuaryFebruary 2013 Issue

Allwood JM, Laursen SE, De Rodriguez CM, Bocken NMP (2006) Well dressed? The present and future sustainability of clothing and textiles in the United Kingdom. University of Cambridge, Cambridge

Ancarani A, Di Mauro C, Fratocchi L, Orzes G, Sartor M (2015) Prior to reshoring: a duration analysis of foreign manufacturing ventures. Int J Prod Econ 169:141-155

Armstrong L (2015) How Burberry brought Britishness back into fashion. The Telegraph, 22 April. Online: http://www.telegraph.co. uk/luxury/womens-style/69146/burberrys-london-in-la-showbrought-britishness-back-into-fashion.html. Accessed 26 June 2015
Bailey D, De Propris L (2014) Manufacturing reshoring and its limits: the UK automotive case. Cambridge J Reg, Econ Soc 7(3):379-395

Bain \& Company (2014) Luxury goods worldwide market study fallwinter 2014: the rise of the borderless consumer. Bain and Company, London

BBC (2007) Burberry defends factory closure. Online: http://www.news. bbc.co.uk/2/hi/uk news/wales/6400995.stm. Accessed 10 December 2015

Blank T (2015) Christopher bailey brings Burberry into the twenty-first century. The WJS magazine, 18 June

Blyton P, Jenkins J (2012) Mobilizing resistance: the Burberry workers' campaign against factory closure. Sociol Rev 60:1

British Fashion Council (BFC) (2012) Future for fashion: strategic considerations for growth. BFC, London

Bromley D (2002) Comparing corporate reputations: league tables, quotients, benchmarks, or case studies? Corp Reput Rev 5(1):35-50

Bruce M, Daly L (2011) Adding value: challenges for UK apparel supply chain management-a review. Prod Plan Control 22(3):210-220

Brun A, Castelli C (2008) Supply chain strategy in the fashion industry: developing a portfolio model depending on product, retail channel and brand. Int J Prod Econ 116(2):169-181

Brun A, Caniato F, Caridi M, Castelli C, Miragliotta G, Ronchi S, Spina $G$ (2008) Logistics and supply chain management in luxury fashion retail: empirical investigation of Italian firms. Int J Prod Econ 114(2):554-570

Buckley PJ, Ghauri PN (2004) Globalisation, economic geography and the strategy of multinational enterprises. J Int Bus Stud 35(2):81-98

Burberry (2010) Burberry annual report 2009/2010. Burberry, London

Burberry (2015a) Burberry annual report 2014/2015. Burberry, London

Burberry (2015b) Burberry strategic review 2014/2015. Burberry, London

Burberry IPO Prospectus (2002) Burberry group global offer of shares. Burberry, London

Butler S (2015) Burberry to invest at least $£ 50 \mathrm{~m}$ in new trench coat factory. The Guardian, 3 November. http://www.theguardian. com/business/2015/nov/03/burberry-invest-50m-new-trenchcoatfactory-leeds. Accessed 5 November 2015

Caniato F, Caridi M, Castelli C, Golini R (2011) Supply chain management in the luxury industry: a first classification of companies and their strategies. Int J Prod Econ 133(2):622-633

Caniato F, Caridi M, Moretto A (2013) Dynamic capabilities for fashionluxury supply chain innovation. Int J Retail Distrib Manag 41(11/ 12): $940-960$

Casadesus-Masanell R, Ricart JE (2010) From strategy to business models and onto tactics. Long Range Plan 43(2):195-215

Christopher M, Lowson RH, Peck H (2004) Creating agile supply chains in the fashion industry. Int J Retail Distrib Manag 32(8):367-376

Chu K, Fujikawa M (2015) Burberry revamps its image in Japan, Wall Street Journal, 14 August

Collins L (2009) Check mate: Burberry's working class hero. New Yorker, 14 September, $72-81$

Collins M, Weiss M (2015) The role of provenance in luxury textile brands. Int J Retail Distrib Manag 43(10/11):1030-1050

Cooper H, Miller D, Merrilees B (2015) Restoring luxury corporate heritage brands: from crisis to ascendency. J Brand Manag 22(5):448-466

Cowe R (1998) Burberry fails to weather the Asia storm. The Guardian, 25 June 1998

De Backer K., Menon C, Desnoyers-James I, Moussiegt L (2016) Reshoring: Myth or Reality? OECD Science, Technology and Industry Policy Papers, No. 27, OECD Publishing, Paris. doi: $10.1787 / 5 \mathrm{jm} 56 \mathrm{frbm} 38 \mathrm{~s}-\mathrm{en}$

Denzin NK, Lincoln YS (2000) Introduction: the discipline and practice of qualitative research. In: Denzin NK, Lincoln YS (eds) Handbook of qualitative research, 2nd edn. Sage, Thousand Oaks, CA, pp. 1-28

Dicken P (2007) Global shift, 5th edn. Guilford Press, New York 
EEF/Squire Sanders survey (2014) Gradual re-shoring of manufacturing continuing - EEF/Squire Sanders survey. http://www.eef.org. uk/releases/uk/2014/Gradual-re-shoring-of-manufacturingcontinuing-EEFSquire-Sanders-survey.html. Accessed 10 June 2014

Ellram LM, Tate WL, Petersen KJ (2013) Offshoring and reshoring: an update on the manufacturing location decision. J Supply Chain Manag 49(2):14-22

Felsted A (2014) Made in Britain: fashion retailers return to UK manufacturing. Financial Times, 24 August 2014

Fernie J, Grant DB (2015) Fashion Logistics: Insights into the Fashion Retail Supply Chain. Kogan Page Publishers, London

Finch J, May T (1998) Reputations: putting a zip in a Burberry. The Guardian, 25 June 1998

Foresight (2013) The future of manufacturing: a new era of opportunity and challenge for the UK summary report. The Government Office for Science, London

Fratocchi L, Di Mauro C, Barbieri P, Nassimbeni G, Zanoni A (2014) When manufacturing moves back: concepts and questions. J Purch Supply Manag 20(1):54-59

Fratocchi L, Ancarani A, Barbieri P, Di Mauro C, Nassimbeni G, Sartor M, Zanoni A (2015) Manufacturing back-reshoring as a nonlinear internationalization process. In: Verbeke A, Drogendijk R (eds) Van Tulder R. Emerald Group Publishing Limited, The Future of Global Organizing, pp. 365-403

Fratocchi L, Ancarani A, Barbieri P, Di Mauro C, Nassimbeni G, Sartor M, Vignoli M, Zanoni A (2016) Motivations of manufacturing reshoring: an interpretative framework. Int J Phys Distrib Logist Manag 46(2):98-127

Gerring J (2004) What is a case study and what is it good for? Am Polit Sci Rev 98(2):341-354

Goodrum AL (2005) The national fabric: fashion, Britishness, globalization. Berg, Oxford

Grappi S, Romani S, Bagozzi RP (2015) Consumer stakeholder responses to reshoring strategies. J Acad Mark Sci 43(4):453-471

Gray JV, Skowronski K, Esenduran G, Johnny Rungtusanatham M (2013) The reshoring phenomenon: what supply chain academics ought to know and should do. J Supply Chain Manag 49(2):27-33

Hammer M, Plugor R, Nolan P, Clark I (2015) New industry on a skewed playing field: supply chain relations and working conditions in UK garment manufacturing. University of Leicester, Leicester

Hammersley M, Gomm R (2004) Introduction. In: Gomm R, Hammersley M, Foster P (eds) Case study method: key issues. Key Texts. Sage, London, pp. 1-16

Holweg M, Helo P (2014) Defining value chain architectures: linking strategic value creation to operational supply chain design. Int J Prod Econ 147:230-238

Interbrand (2015) Interbrand releases 2015 best global brands report. Interbrand, London

Jones R (2002) The apparel industry. Blackwell Science Ltd, Aylesbury

Jones R (2007) In the news at last! Journal of Fashion Marketing and Management: An International Journal doi:10.1108 /jfmm.2007.28411baa.001

Key Note (2014) Clothing manufacturing market reports 2014, 18th edn. Key Note, London

Key Note (2015) Clothing manufacturing market reports 2015, 19th edn. Key Note, London

Khan O (2015) Luxury consumption moves east. J Fash Mark Manag 19(4):347-359

Kim B (2013) Competitive priorities and supply chain strategy in the fashion industry. Qual Mark Res Int J 16(2):214-242

Kinkel S (2012) Trends in production relocation and backshoring activities: changing patterns in the course of the global economic crisis. Inter J Oper Prod Manag 32(6):696-720

Kinkel S (2014) Future and impact of backshoring - some conclusions from 15 years of research on German practices. J Purch Supply Manag 20(1):63-65
Kinkel S, Maloca S (2009) Drivers and antecedents of manufacturing offshoring and backshoring:a German perspective. J Purch Supply Manag 15(3):154-165

Lane C, Probert J (2006) Domestic capabilities and global production networks in the clothing industry: a comparison of German and UK firms' strategies. Soc Econ Rev 4(1):35-67

Lee HL (2002) Aligning supply chain strategies with product uncertainties. Calif Manag Rev 44(3):105-119

Lee HL (2004) The triple-a supply chain. Harv Bus Rev 82(10):102-113

Lincoln Y, Guba E (1985) Naturalist inquiry. Sage, Beverly Hills, CA

Macchion L, Danese P, Vinelli A (2015) Redefining supply network strategies to face changing environments. A study from the fashion and luxury industry. Oper Manag Res 8(1-2):15-31

Martinez-Mora C, Merino F (2014) Offshoring in the Spanish footwear industry: a return journey? J Purch Supply Manag. doi:10.1016/j. pursup.2014.07.001

McLaren R, Tyler DJ, Jones RM (2002) Parade-exploiting the strengths of "made in Britain" supply chain. J Fash Mark Manag: An Int J 6(1):35-43

Mehrjoo M, Pasek ZJ (2015) Risk assessment for the supply chain of fast fashion apparel industry: a system dynamics framework. Int J Prod Res. doi:10.1080/00207543.2014.997405

Miles MB, Huberman AM (1994) An expanded sourcebook: qualitative data analysis, 2nd edn. Sage, Thousand Oaks, CA

Moore C, Birtwistle G (2004) The Burberry business model: creating an international luxury fashion brand. Int J Retail Distrib Manag 32(8): $412-422$

Moore C, Fernie J (2004) Retailing within an international context. In: Bruce M, Moore C, Birtwistle G (eds) International retail marketing: a case study approach. Elsevier Butterworth-Heinemann, Oxford, pp. 3-37

Narasimhan R, Kim SW, Tan KC (2008) An empirical investigation of supply chain strategy typologies and relationships to performance. Int J Prod Res 46(18):5231-5259

Pickles J, Plank L, Staritz C, Glasmeier A (2015) Trade policy and regionalisms in global clothing production networks. Camb J Reg, Econ Soc 8(3):381-402

Pike A (2013) Economic geographies of brands and branding. Econ Geogr 89(4):317-339

Pisano G, Shih W (2012) Producing prosperity: why America needs a manufacturing renaissance. Harvard Business Review, pp 94-102

Popp A (2000) Swamped in information but starved of data: information and intermediaries in clothing supply chains. Supply Chain Manag: Int J 5(3):151-161

Porter ME (1985) Competitive advantage: creating and sustaining superior performance. The Free Press, New York

Purvis L, Gosling J, Naim MM (2014) The development of a lean, agile and leagile supply network taxonomy based on differing types of flexibility. Int J Prod Econ 151:100-111

PwC (2013) Going beyond reshoring to right-shoring. PwC, London

Roh J, Hong P, Min H (2014) Implementation of a responsive supply chain strategy in global complexity: the case of manufacturing firms. Int J Prod Econ 147:198-210

Teece DJ (2010) Business models, business strategy and innovation. Long Range Plan 43(2):172-194

The Economist (2001) Rose Marie Bravo, the American behind Burberry's revival The Economist, 3 February 2001

Tokatli N (2012) Old firms, new tricks and the quest for profits: Burberry's journey from success to failure and back to success again. J Econ Geogr 12:55-77

von Massow M, Canbolat M (2014) A strategic decision framework for a value added supply chain. Int J Prod Res 52(7):1940-1955

Welch C, Marschan-Piekkari R, Penttinen H, Tahvanainen M (2002) Corporate elites as informants in qualitative international business research. Int Bus Rev 11:611-628

Yin RK (2009) Case study research: design and methods, 4th edn. Sage, Thousand Oaks, CA 